University of Windsor

Scholarship at UWindsor

2014

\title{
Is the red dragon green? An examination of the antecedents and consequences of environmental proactivity in China
}

Kent Walker Dr.

Odette School of Business

$\mathrm{Na} \mathrm{Ni} \mathrm{Dr.}$

Hong Kong Polytechnic University

Weidong Huo

Southwestern University of Finance and Economics

Follow this and additional works at: https://scholar.uwindsor.ca/odettepub

Part of the Business Administration, Management, and Operations Commons, and the Business Law, Public Responsibility, and Ethics Commons

\section{Recommended Citation}

Walker, Kent Dr.; Ni, Na Dr.; and Huo, Weidong. (2014). Is the red dragon green? An examination of the antecedents and consequences of environmental proactivity in China. Journal of Business Ethics.

https://scholar.uwindsor.ca/odettepub/75

This Article is brought to you for free and open access by the Odette School of Business at Scholarship at UWindsor. It has been accepted for inclusion in Odette School of Business Publications by an authorized administrator of Scholarship at UWindsor. For more information, please contact scholarship@uwindsor.ca. 


\title{
Is the Red Dragon Green? An Examination of the Antecedents and Consequences of Environmental Proactivity in China
}

\begin{abstract}
China is the world's second largest economy and the largest emitter of carbon dioxide, yet we know little about environmental proactivity in the most populated country in the world. We address this gap through a survey of 161 Chinese companies with two respondents per firm $(\mathrm{N}=322)$ where we seek to identify the antecedents and consequences of environmental proactivity. We identify two categorizations of environmental proactivity: Environmental operational improvements and environmental reporting. We find that ecological motivations and regulatory stakeholder pressure are positively related to both types of environmental proactivity, and external stakeholder pressure is negatively related to environmental reporting. Furthermore, we find that (1) if a firm is environmentally proactive (as it relates to either measure) and they are ecologically motivated, there is a positive and significant cost advantage, and (2) if a firm makes use of environmental operational improvement and they are competitively motivated, there is a positive and significant reputation advantage. Implications for researchers, managers, and policy-makers in China are discussed.
\end{abstract}

Key Words: China, Competitive Advantage, Environmental Proactivity, Motivation, Reputation, Stakeholder Pressure 


\section{Is the Red Dragon Green? An Examination of the Antecedents and Consequences of Environmental Proactivity in China}

We are now undoubtedly witnessing the dramatic ecological effects of the industrial revolution which include but are not limited to climate change, deforestation, depleted and polluted oceans and fresh water, and unprecedented losses in biodiversity (Pacala and Socolow, 2004). Scientists and policy makers have warned that we are now entering the sixth great extinction since the birth of the planet, the last of which occurred during the reign of the dinosaurs in the late cretaceous period (Gore, 2009). Unlike the past, however, where natural events such as asteroid collisions or naturally occurring climate change were to blame, today, the blame rests primarily with humans. The anthropogenic causes of our current ecological state are garnering increasing attention within academia, and because organizations are a major contributing factor, management scholars have increasingly turned their attention to this important area (Berchicci and King, 2007; Lockett, Moon and Visser, 2006; Starik, 2006).

In this study, we investigate proactive environmental strategies, meaning strategies "that seek to reduce the environmental impacts of operations beyond regulatory requirements" (Delmas, Hoffman, and Kuss, 2011: 119). In particular, our research focuses on the antecedents (i.e., managerial motivations and stakeholder pressures) and consequences (i.e., cost advantages, reputation and innovation) of environmental proactivity in China.

To date, research examining environmental proactivity has tended to investigate Western societies (e.g., Darnall, Henriques and Sadorsky, 2010; Delmas and Toffel, 2008; Rueda-Manzanares, Aragon-Correa and Sharma, 2008). Consequently, current management research in the area does not adequately reflect the emergence of developing countries as major players in the world economy. 
Similarly, research examining the more general corporate social responsibility (CSR) area has overwhelmingly focused on developed markets (Gao, 2009; Ip, 2008). This focus is not consistent with the economic growth we have seen in emerging markets. We believe that a close examination on environmental proactivity and its antecedents in different institutional contexts is important given the global economy and global environmental problems that require contingent solutions. For example, the antecedents and consequences of environmental proactivity may be different in China versus the United States or other Western countries. As the second largest economy in the world and the largest emerging market, China, is of particular interest (Ye and Zhang, 2011). Despite China's tremendous economic growth, we know little of its growth as it relates to CSR and environmental responsibility specifically (Gao, 2009). As the largest carbon emitter in the world and a country that burns twice as much coal as the United States (Gore, 2009) the dearth of academic research examining the environmental performance of China represents a large gap in the literature.

Furthermore, it is important to investigate environmental proactivity in China to supplement our understanding and conceptualization of this complex construct. In particular, we need to study it in different contexts to see how it may, or may not be, contingent on a particular institutional environment. Furthermore, China presents an interesting context to study environmental proactivity because of the need to balance tremendous economic growth with equally tremendous environmental damage. As an example of the latter, Chinese officials currently estimate that approximately 700,000 people die annually in China from causes related to poor environmental conditions (Time, March 25, 2013). All economies must balance a desire for continuous growth with the recognition of limited resources in a finite planet. China represents a dramatic example where this need for balance is highly visible. Lastly, researchers 
have increasingly found that environmental management is not a universal prescription or a one-size-fits-all approach (Barnett, 2007; Berchicci and King, 2007; Brammer and Millington, 2008). Given the significantly different context in China versus most Western societies, we can reasonably expect differences in their environmental proactivity.

To examine the antecedents and consequences from a proactive environmental approach in China we surveyed 161 companies in the province of Sichuan with two representatives per firm - the environmental manager and a top executive — for a total of 322 respondents. We found that an ecological motivation and regulatory stakeholder pressures were positively related to environmental proactivity, and external stakeholder pressures were negatively related to environmental proactivity. We also found that an ecological motivation was necessary to gain a perceived cost competitive advantage from environmental proactivity, and that a competitive motivation was necessary to gain a perceived reputation competitive advantage from environmental proactivity.

The remainder of the paper proceeds as follows: First, we review the literature specific to the variables in our study model. Second, we develop hypotheses to (1) explain environmental proactivity related to motivations and stakeholder pressures, and (2) determine the relationship between environmental proactivity and competitive advantage. Third, we describe our methodology and results. Lastly, before concluding, we present our discussion, and the implications and limitations in our study.

\section{Literature Review}

Proactive environmental strategies exist beyond what is required by law (Delmas et al., 2011; Sharma 2000). Such strategies seek to minimize a corporation's 
negative environmental impacts and perhaps even improve current environmental conditions. Environmental proactivity is often demonstrated through environmental operational improvements (e.g, waste reduction, closed-loop systems, life-cycle analysis, employee training) and environmental reporting (e.g., internal and external accounting procedures, environmental indicators and goals, sustainability reports) (Darnall et al. 2010; Delmas et al. 2011; Hart, 2005; Nash and Ehrenfeld, 1997; Welford, 1998). We accordingly examine two types of environmental proactivity: operational improvements and environmental reporting.

In their comprehensive qualitative study Bansal and Roth (2000) identified three environmental motivations: competitive, legitimation and ecological responsibility. A competitive motivation stems from a desire to further an organization's competitiveness and profitability. A legitimation motivation stems from a desire to be perceived as legitimate by stakeholders. Lastly, an ecological motivation stems from a desire to protect the natural environment. We view a legitimacy motivation as very similar to a competitive motivation, in that the desire for legitimacy is ultimately a desire to enhance the competitiveness of the organization. We, therefore, include the legitimation motivation as part of the competitive motivation where an organization seeks to further their competitiveness and profitability.

While the importance of each type of motivation is likely to vary based on the context, we anticipate that these motivations identified in a Western context will still apply in China. In particular, Chinese managers are just as likely as Western managers to be attracted to environmental proactivity because of the potential of a competitive advantage (a competitive or legitimation motivation) or because they care 
for the natural environment (ecological motivation). Accordingly, we seek to measure both types of motivation in our study.

The literature identifies a second common motivation for the adoption of proactive environmental strategies, stakeholder pressures. Researchers have found that proactive environmental strategies are related to perceived stakeholder pressure from regulators (Delmas and Montes-Sanchez, 2010; Delmas and Montiel, 2008; Majumdar and Marcus, 2001) and external stakeholders (Darnall et al., 2010; Delmas, 2001; Hart, 2005; Henriques and Sadorsky, 1996, 1999; Sharma and Henriques, 2005). Similarly, given the Chinese context of our research we focus on these two particular groups of stakeholders. Researchers have found that in the adoption of CSR practices of firms within China, both internal (i.e., employees) and societal stakeholders (i.e., general public, NGOs, unions, etc.) yield little power (Lin, 2010; Liu et al., 2010; Tsoi, 2010). We accordingly limit our investigation to external and regulatory stakeholders, although as we state in our methodology, we do include other stakeholder groups to confirm they are not applicable to our study context.

Extant research in China mainly focuses on the role of regulators or political influence in determining firms' environmental strategies or performance. This focus stems from the traditional perspective of the 'state-led' pseudo market of China where government plays a significant role in shaping corporate behaviors (FranceschHuidobro, Lo, and Tang, 2012; Lo and Fryxell, 2005; Lo, Fryxell, and Van Rooij, 2009; Ma and Ortolano 2000; Tang, Lo and Fryxell, 2003; Tao and Mah, 2009; Van Rooij, 2006). Nevertheless, studies that also investigate motivations or the role of other types of stakeholders have started to emerge (e.g., Liu et al., 2010; Zhang et al., 2008; Zhu, Sarkis and Lai, 2007). For example, Zhang et al. (2008) found that regulatory pressure was not statistically related to the corporate environmental 
management performance of their sampled firms. They further argued that this was because firms in the studied region, Jiangsu Province in China, have achieved basic compliance to local environmental standards and laws. In contrast, Zhu et al. (2007) evidenced the influence of both regulatory and market pressures on the adoption of green supply chain management (GSCM) by Chinese automobile supply chain enterprises.

Examining the consequences to environmental proactivity, research has moved beyond a simple examination of the effects on profitability to more specific competitive advantages (Berchicci and King, 2007). Similarly, in this study we examine competitive advantages manifested through costs, reputation and innovation (Delmas et al., 2011). While competitive advantages to environmental proactivity have been well documented in Western contexts (e.g., Ambec and Lanoie, 2008; Bansal and Clelland, 2004; Hart, 1995; Hart and Ahuja, 1996; Miles and Covin, 2000; Rooney, 1993; Russo and Fouts, 1997), we know of no research that has empirically examined the relationship between environmental proactivity and competitive advantage in the largest emerging market, China (Ye and Zhang, 2011).

In this study we expand on previous literature by examining environmental proactivity within China. Yet our study is more than a reliability test of previous research applied to a different study context. Not only do we adapt our variables and hypotheses to the specific study context to enhance relevance, but we also consistently find differences in the antecedents and consequences of environmental proactivity in China versus that of Western countries. This furthers our conceptualization of environmental proactivity and supports the contention that environmental management is not a universal prescription or a one-size-fits-all approach (Barnett, 2007; Berchicci and King, 2007; Brammer and Millington, 2008). 


\section{Hypothesis Development}

To garner an understanding of environmental proactivity in China we seek to understand the antecedents to greater proactivity and the consequences. Specifically, we examine motivations for environmental proactivity and stakeholder pressures as antecedents, and competitive advantage through cost advantages, reputation and innovation as consequences. Figure 1 represents our study model.

Insert Figure 1 about here

Motivation and Environmental Proactivity

Bansal and Roth (2000) state that it is important to understand the motives for environmental proactivity for two reasons. The first is limited to organizational theorists who can use this understanding to predict when such behaviour is likely to occur. The second is broader with implications for researchers, managers, and governments who can learn how to foster environmentally proactive organizations.

Given such implications, it is not surprising that a number of researchers have investigated reasons for environmental proactivity. Researchers have found that organizational champions pushing for a more proactive environmental approach (Andersson and Bateman, 2000), regulations (Marcus and Geffen, 1998; Majumdar and Marcus, 2001), financial benefits (Margolis and Walsh, 2003; Orlitzky, Schmidt and Rynes, 2003), and managerial cognitions including interpretations of environmental issues as threats or opportunities (Ghobadian et al., 1995; Lee and Rhee, 2007; Sharma, 2000) can all influence a firm's environmental approach.

In their detailed qualitative analysis Bansal and Roth (2000) identified three main motivations for environmental proactivity: competitiveness, legitimation and 
ecological responsibility. Competitiveness represents the belief that environmental proactivity will improve long-term profitability. Legitimation represents the belief that environmental proactivity will enable firms to attain the necessary resources, reduce uncertainty, and ultimately enhance their survivability (DiMaggio and Powell, 1983; Meyer and Rowan, 1977). Lastly, ecological responsibility represents the belief that environmental proactivity is the right thing to do from a moral and ethical standpoint. As stated above, we combined the competitiveness and legitimation motivations as we viewed the ultimate end to these motives to be increased competitiveness.

We sought to examine to what extent these two types of motivation were influential in determining the environmental proactivity of Chinese firms. Given that Bansal and Roth (2000) qualitatively identified these types of motivations as determinants of greater environmental responsibility, we predict a positive relationship between each type and environmental proactivity.

We believe this is particularly applicable within China because Chinese firms are increasingly incorporating environmental management into their overall corporate social responsibility practices, primarily because of influences from the different levels of Chinese governments and external parties from developed countries (Lai and Wong, 2012; Lo et al. 2009; Sarkis, Ni and Zhu, 2011; Tang et al., 2003; Yuan, Bi and Moriguichi, 2006). Similarly, more and more Chinese firms link such practices to their economic analysis or personal moral requirements (Wang and Qian, 2011).

A competitive motivation stems from a belief that a firm can gain a competitive advantage through an environmental proactive strategy. Indeed, research has found that environmental proactivity can reduce costs by lowering compliance costs, reducing or avoiding legal liabilities, reducing waste, and improving efficiency 
and productivity (Ambec and Lanoie, 2008; Hart, 1995; Hart and Ahuja, 1996; Rooney, 1993). It may improve legitimacy (Bansal and Clelland, 2004), and strengthen a firm's reputation (Hart, 1995; Miles and Covin, 2000). It may also lead to the development of new market opportunities and better access to markets (Ambec and Lanoie, 2008), product differentiation (Ambec and Lanoie, 2008; Porter and van der Linde, 1995), and the selling of pollution control technology (Ambec and Lanoie, 2008). With so many potential advantages to an environmentally proactive approach, a desire for greater competiveness can lead to environmental proactivity.

\section{H1: A competitiveness motivation will be positively related to environmental proactivity.}

In addition, managers may simply be motivated to engage in environmental proactivity because they believe it is the right thing to do from a moral or ethical standpoint (Bansal and Roth, 2000). We can reasonably expect that if managers are motivated by ecological responsibility this will lead to greater environmental proactivity. That is, if a manager believes that environmental proactivity is important and the right thing to do, then this will be related to environmental proactivity within the organization.

$\mathrm{H} 2$ : An ecological responsibility motivation will be positively related to environmental proactivity.

\section{Stakeholder Pressure and Environmental Proactivity}

We define stakeholders as "any group or individual who can affect or is affected by the achievement of the organization's objectives" (Freeman, 1984: 46), or in other words, as someone who has a stake in the organization. Ultimately, these stakeholders pose various institutional pressures (i.e., coercive, normative, and mimetic pressures) that motivate firms to enhance or limit environmental proactivity (Darnall et al., 2010; Delmas, 2001; Hart, 2005; Henriques and Sadorsky, 1996, 1999; 
Sharma and Henriques, 2005). In theory, all stakeholders are important to an organization, but in reality, firms must necessarily limit the importance they can attach to various stakeholder groups (Jamali, 2008; Lee, 2011). Indeed, researchers have noted that some stakeholders are of higher importance than others (Davis and Thompson, 1994; Mitchell, Agle and Wood, 1997).

Researchers studying emerging markets have theorized that stakeholder pressures are stronger in developed than in developing markets where social and environmental responsibility are of less importance to stakeholders in general (Gao, 2009; Li and Zhang, 2010; Sharfman and Fernando, 2008; Ye and Zhang, 2011). However, we know of little empirical research that supports this contention or research that shows how pressures might differ per stakeholder group. Indeed, even within China we can expect differences in stakeholder pressures across geographic areas. For example, local residents in some urban areas of China may have higher environmental awareness due to variance in institutional and economic variances across regions (Huang et al., 2006; Liu and Lu, 2002). However, overall, internal and societal stakeholders have yet to play a strong role in terms of monitoring business' environmental activities (Tang and Zhan, 2008; Yang, 2005).

By nature, external stakeholders (e.g., consumers, suppliers, competitors, trade associations, banks, etc.) are limited in their capacities to influence firm behaviour through external and indirect means (Sharma and Henriques, 2005). That is, they must be perceived as important by internal (or regulatory) stakeholders who have the ability to influence firm behaviour. External stakeholders seeking to influence firm environmental proactivity may do so through strict contract or purchase requirements, protests, boycotts, negative media attention, and through attempts to intensify regulatory requirements, exerting coercive pressures on firms. Firms seeking to avoid 
negative public attention may then be driven toward greater environmental proactivity (Bansal and Roth, 2000) by showing their external stakeholders (e.g., consumers, suppliers) green profiles (Arora and Cason, 1996).

Research in China has found that external stakeholders from developed countries are pressuring Chinese firms in their supply chain to increase their environmental performance (Lai and Wong, 2012; Zhu et al., 2007). In addition, both international and local customers in China are increasingly demanding greater environmental proactivity from Chinese firms (e.g., Lau and Waldmeir, 2010; Sarkis et al., 2011; Yuan et al., 2006). Accordingly, we predict that perceived pressures from external stakeholders will be related to greater environmental proactivity:

H3: Perceived external stakeholder pressure will be positively related to environmental proactivity.

Regulatory stakeholders include government officials with the power and authority to create and enforce environmental standards (Darnall et al., 2010; Fineman and Clarke, 1996; Francesch-Huidobro et al., 2012). Firms are likely to place high importance on regulatory stakeholders as failure to comply with regulatory demands can result in potential liabilities, fines, penalties, and clean-up costs (Bansal and Clelland, 2004). Furthermore, managers may perceive pressure from regulatory stakeholders because of the potential organizational benefits that can be obtained from compliance and working relationships with government. For example, environmental proactivity has been shown to offer regulatory advantages by leading to greater flexibility to adapt to legislative changes (Bansal and Bogner, 2002), the ability to influence environmental laws and regulations (Faucheux et al., 1998; Hart, 1995; Hillman and Hitt, 1999; Miles and Covin, 2000), and to reduce or avoid legal liabilities (Hart, 1995; Rooney, 1993). 
Recently, environmental management has been one of the top issues on the political agenda for government in China (Francesch-Huidobro et al., 2012; Yuan et al., 2006). Governments at different levels (e.g., central, provinces, cities, and counties) have launched a series of regulatory policies and market-based approaches in order to motivate corporations to implement environmental management (Lo and Fryxell, 2005; Ma and Ortolano 2000; Tang et al., 2003; Zhang et al., 2008). Accordingly, we predict that perceived pressures from regulatory stakeholders will be related to greater environmental proactivity:

H4: Perceived regulatory stakeholder pressure will be positively related to environmental proactivity.

Environmental Proactivity and Competitive Advantage

Research examining the financial benefits to environmental performance has tended to examine three main areas of competitive advantage: cost, reputation and innovation (e.g., Delmas et al., 2011). Research done in developed countries has found that environmental performance can reduce costs by lowering compliance costs, reducing waste, improving efficiency and productivity, and reducing or avoiding legal liabilities (Ambec and Lanoie, 2008; Hart, 1995; Hart and Ahuja, 1996; Rooney, 1993). Research has also found that environmental performance can strengthen firm reputation both directly (Hart, 1995; Miles and Covin, 2000), and indirectly through greater appeal to consumers (Miles and Covin, 2000), improvements in legitimacy (Bansal and Clelland, 2004), and through the ability to influence environmental laws and regulations (Faucheux et al., 1998; Hart, 1995; Hillman and Hitt, 1999; Miles and Covin, 2000). Lastly, environmental performance can lead to a competitive advantage related to innovation through product differentiation (Ambec and Lanoie, 2008; Porter and van der Linde, 1995), the selling of pollution control technology (Ambec and Lanoie, 2008), the creation of entry 
barriers (Dean and Brown, 1995; Hart, 1995; Russo and Fouts, 1997), and the development of new market opportunities and better access to markets (Ambec and Lanoie, 2008). Whether these effects occur in a developing market remains unclear, and in particular, we know of no research that has empirically examined the relationship between environmental proactivity and competitive advantage in the largest emerging market, China (Ye and Zhang, 2011).

Within China, as compared to most Western countries, firms tend to operate in a fiercely low-cost external business environment. That is, currently China's main competitive advantage is its low-cost environment, established primarily through relatively low wages. Since costs are already extremely low, it is likely to be highly difficult to gain further cost advantages through environmental proactivity. We do, however, still believe it is possible, but only when managers are ecologically motivated.

If top management's drive for environmental proactivity stems from an ecological instead of a competitive motivation, the organizational culture and leadership would be significantly different. That is, employees may recognize that a firm's environmental proactivity is not simply another means for management to minimize costs, but is part of the organizational norm and something top management believes as being the right thing to do (Bansal and Roth, 2000). This recognition and ultimate embracement of environmental proactivity may then, paradoxically, result in additional cost savings. Such cost savings may result from an organizational culture that recognizes and rewards (financially or otherwise) ecological responsibility. Likewise, this culture and leadership may drive mangers to make necessary short-term investments to gain longer-term ecological and financial benefits. For example, managers might be willing to purchase more efficient technology despite the upfront 
costs. Managers may also be more receptive to taking risks to further their environmental proactivity as they feel obligated to do so based on their belief that it is the right or ethical thing to do. Lastly, within such a culture employees are likely to be more receptive to, and aware of finding, additional means to furthering environmental proactivity. In sum, through the impact on managers and employees (Mayer et al., 2009; Sharma, 2000; Somers, 2001), firms within China with ecologically motivated senior executives may gain a cost competitive advantage to environmental proactivity

H5: The interaction between environmental proactivity and cost advantage will have a positive association with ecological motivations.

In contrast, to gain a reputation advantage in China, we believe that firms must be competitively motivated. In a systematic review of the corporate reputation literature Walker (2010) noted that the most commonly used definition of reputation comes from Fombrun (1996: 72) who defined it as "A perceptual representation of a company's past actions and future prospects that describes the firm's overall appeal to all of its key constituents when compared with other leading rivals". This definition clearly states that reputation is based on a comparison to rivals.

Accordingly, we believe that in order to gain a reputation advantage from environmental proactivity managers need to be motivated by competition so that they are always seeking to outperform their competitors, and are thus perceived as more environmentally proactive to stakeholders. This is likely to result in a constant oneupping as these externally driven managers seek to have higher environmental proactivity than rivals. Two points arise from this observation. First, because a firm's reputation is based on stakeholders' expectations derived from a comparison to "leading rivals" (Fombrun, 1996), if a firm is continuously outperforming the environmental proactivity of competitors, they are likely to gain a reputation advantage. Second, it is possible that for managers that are competitively motivated 
their environmental proactivity is more symbolic than substantive (Walker and Wan, 2012), meaning they can gain a perceived reputational advantage but not a cost advantage.

H6: The interaction between environmental proactivity and reputation advantage will have a positive association with competitive motivations.

Lastly, while we believe that both cost and reputational advantages to environmental proactivity will occur in China depending on managerial motivations, we do not predict advantages related to greater innovation. In general, China has not to date demonstrated an ability to develop world leading innovative green products or services. In fact, if anything the opposite is true where Western firms have struggled to maintain their environmentally responsible image when working with Chinese firms that tend to have a poor environmental image (Lai and Wong, 2012). Accordingly, we do not make a hypothesis for the relationship between environmental proactivity and innovation. Despite the lack of a hypothesis we keep innovation in the study as a non-significant relationship would be in contrast to findings in Western countries (e.g., Delmas et al., 2011), and thus interesting in its own right.

\section{Method}

Context

This study was conducted in Zigong, a prefecture-level city of Sichuan province in southwest China. China, one of the major industrializing countries with rapid economic development in the past thirty years, is faced with a dilemma of significant resource and environmental constraints. This is more evident in our research site area, which is geographically distant from other major cities in China. The city is well known for having varied manufacturing industries such as natural gas, coal, inorganic chemicals, and salt production, thus it provides excellent research facilities for understanding corporate environmental management by Chinese firms. 
There is very little publicly available data on the environmental proactivity of Chinese firms in general, and within the manufacturing industry in the province of Sichuan there is also no publicly available data on corporate financial performance. That is, there is no reliable secondary data available on environmental proactivity, its antecedents, or its consequences. Accordingly, we collected primary data through surveys with a multi-item scheme and with multiple respondents per firm (Delmas et al. 2011).

We first obtained the complete company directory through the Bureau of Commerce of Zigong (BCZ). After dropping firms that were not accessible or had gone through bankruptcy, a total of 330 companies were included in the survey and questionnaires were sent to them facilitated by BCZ, the Zigong Branch of Chengdu Customs, and Zigong Environmental Protection Bureau (it is common to conduct surveys in China through government authorities in order to increase response rates). In order to minimize the risk of common method bias (Podsakoff et al., 2003), for each company we used multiple respondents as we sought information on environmental proactivity from environmental managers, and information on competitive advantage, motivations and stakeholder pressures from top managers, respectively. Environmental managers are in the best position to explain their environmental strategy and managerial discretion as it relates to the natural environment, and as the key decision makers top managers are in the best position to explain the financial benefits, their motivations for environmental proactivity and stakeholder pressures.

Some of the surveyed firms had specific people in charge of environmental management (e.g., with titles such as departmental managers of environmental management, general managers in charge of environmental management, etc.). For 
those without specific titles set up for environmental management, managers with the best knowledge of internal environmental management (e.g., product managers, project managers, $R \& D$ managers, security managers, etc.) filled out the questionnaires. Top managers included vice-presidents, chairpersons, general managers, or owners. Lastly, we dropped firms from the analysis that returned questionnaires answered by single respondents, leaving us with a final usable data of 161 valid observations (response rate $=48.8 \%$ ). That is, our final sample consisted of 322 participants in 161 firms.

The average age of our managers was 36 years old, 55 percent were male and 45 percent female, and over 80 percent had a University education at minimum. Regarding their work experience, the mean number of years participants were with their current company was six, the mean number of years they were in their current position was five, and the mean number of years of managerial experience was six and a half.

We developed each construct discussed in detail below based on work from previous scholars (Darnall et al., 2010; Delmas et al., 2011; Hart, 2005; Nash and Ehrenfeld, 1997; Welford, 1998), and a pilot test of 27 Chinese firms within our specific research context. Lastly, prior to the pilot test we also asked industry experts within China to check the face validity of our constructs for our setting (Delmas et al. 2011). To test the validity of dependent and independent variables we performed exploratory factor analyses using principle component analysis with Varimax rotation. Dependent Variables

Environmental Proactivity. A proactive environmental strategy is characterized by a strong commitment to the natural environment going significantly beyond legal requirements. This commitment is often demonstrated and measured 
through environmental operational improvements (e.g, waste reduction, closed-loop systems, life-cycle analysis, employee training) and environmental reporting (e.g., internal and external accounting procedures, environmental indicators and goals, sustainability reports) (Darnall et al. 2010; Delmas et al. 2011; Hart, 2005; Nash and Ehrenfeld, 1997; Welford, 1998). Within these two broad measures we developed a number of survey questions. Using a factor analysis we identified two valid constructs, both of which had a single Eigen value above 1 and alpha's of .70. The first construct consisted of four items. It focused on environmental operational improvements and asked respondents questions such as: Do you have an internal assessment of the environmental impact of operations? Do you conduct a comprehensive internal environmental audit? The second construct also consisted of four items. It focused on environmental reporting and asked respondents questions such as: Do you have environmental performance indicators/goals? Do you have a formal environmental performance reporting system?

Competitive Advantage. The effect of environmental strategy on competitive advantage has been examined by a number of authors (Christmann, 2000; Delmas et al., 2011; Russo and Fouts, 1997). Given that financial performance data, and in particular accounting measures, were not available for the firms in our sample we used constructs developed by Delmas et al (2011) and added survey questions more particular to our research context where applicable.

Competitive advantage was measured via three constructs: cost advantage, reputation and innovation (Delmas et al., 2011). The examination of three areas of competitive advantage permits a more nuanced investigation into the financial benefits of environmental responsibility (Barnet, 2007). Each item was measured using a 7-point Likert-type scale; all constructs had a single Eigen value above one, 
and the alpha's for competitive advantage, reputation and innovation were as follows: $.73, .70$ and .76 respectively.

The competitive advantage construct consisted of four items examining both domestic and foreign competitors and asked respondents questions such as: We incur lower compliance costs with regulations of environmental issues relative to our domestic competitors; Overall, our environmental strategy improves our relative cost position to foreign competitors.

The reputation construct consisted of two items and measured reputation according to consumers (Delmas et al., 2011). The questions asked respondents to rate the loyalty of existing customers and the attraction of new customers.

The innovation construct consisted of three items and asked respondents about technology development, the development of new, or improvements in existing, processes and operations, and the development of new, or improvements of existing products.

Independent Variables

Motivations. Building off the qualitative research of Bansal and Roth (2000) we developed scale items for two environmental motivations: competitive and ecological responsibility.

Each item in our motivation variables were measured using a 7-point Likerttype scale; both constructs had a single Eigen value above one, and the alpha's for a competitive and an ecological motivation were as follows: .82 and .65 respectively.

The competitive motivation construct consisted of three items and asked respondents questions such as: I chose to invest in environmental responsibilities that will secure my firm with the highest returns; Environmental initiatives must be commercially viable for me to invest in them. The ecological motivation construct 
consisted of four items and asked respondents questions such as: Firms have a responsibility to invest in environmental initiatives; My company is environmentally responsible because it is the right thing to do.

Stakeholder Pressure. The perceptions of managers are of critical importance to understanding stakeholder influence and pressure (Banerjee, 2001; Donaldson and Preston, 1995; Fineman and Clarke, 1996). In turn, managerial perceptions of the stakeholder pressures then influence firm strategy (Darnall et al., 2010; Donaldson and Preston, 1995; Fineman and Clarke, 1996; Henriques and Sadorsky, 1999). Correspondingly, using our survey we asked managers to rate the perceived pressures from various stakeholders.

Given the context of our research in the province of Sichuan we focused on external and regulatory stakeholders as per our hypotheses for stakeholder pressures. Within China both internal (i.e., employees) and societal stakeholders (i.e., general public, NGOs, unions, etc.) yield little power regarding the use of CSR practices of firms (Lin, 2010; Tsoi, 2010). Importantly, this was confirmed in our data as we included multiple groups of stakeholders but they did not produce valid or reliable constructs.

Each construct was measured using a 7-point Likert-type scale where respondents were asked to rate the importance of various stakeholders. Both stakeholder pressure constructs had a single Eigen value above one, and the alpha's for external and regulatory stakeholder pressures were as follows: .74 and .70 respectively. External stakeholders included customers, suppliers, trade associations, competitors and banks. Regulatory stakeholders included all three levels of government relevant to our research context: municipal, provincial and central.

Control Variables 
Firm size. Size was included because larger firms tend to pollute more, and studies have found that larger firms are more likely than smaller firms to integrate environmental practices into their organizations (Chen, Lai and Wen, 2006; LopezGamero, Claver-Cortes and Molina-Azorin, 2008; Moore, 2001; Russo and Fouts, 1997). In addition, previous research has used size as a proxy for firm visibility as highly visible companies are often under increased scrutiny from stakeholders (Adams and Hardwick, 1998; Brammer and Millington, 2008). Increased firm visibility could lead to higher costs associated with increased taxation, fines and litigation for example. It might also lead to increased environmental responsibility as these firms seek to appease the increased demands from stakeholders and to avoid or pre-empt environmental legislation (Brammer and Millington, 2008). Firm size was measured as the total number of employees (Darnall et al., 2010).

In addition, we partly controlled for firm size by only including firms with more than 50 employees. We also created a measure for firm size which was broken down within our sample as follows: 56 percent had between 51-100 employees, 30 percent had between 101-500 employees; six percent had between 501-1000 employees, and eight percent had between 1001-5000 employees.

Export orientation. Firms with greater export orientation may benefit from showing their commitment to environmental protection because this may boost the confidence of foreign customers (Christmann and Taylor, 2001; Darnall et al., 2010). It was measured by following Darnall et al. (2010) by surveying whether the firm's market scope was local (i.e., export orientation $=1$ ), national (i.e., export orientation $=2$ ), regional (i.e., export orientation $=3$ ), or global (i.e., export orientation $=4$ ). This construct ranged from 1 to 4 , with a mean value of 1.99 and a standard deviation of 97. 
Firm age. Older firms have been shown to have greater environmental responsibility (Darnall et al., 2010; Portney and Stavins, 2000). Age was measured as the number of years in operation. The age range in our sample was from 1-73, with a mean age of 14 years and a standard deviation of 12 .

Industry type. Dummy variables were used to control for industry type. Seventy-five percent of the firms in our sample were in manufacturing and 25 percent in service.

Family business. Family businesses have been found to be more socially and environmentally responsible than their peers (Sharma and Sharma, 2011). Only eight percent of the companies in our sample were family run businesses.

\section{Results}

Descriptive statistics and correlations for our study variables are shown in Table I.

Insert Table I about here

Motivation

To test Hypotheses 1 and 2-which predicted that a competitive and an ecological responsibility motivation would be positively related to environmental proactivity-we ran linear regressions across both our measures of environmental proactivity (environmental operational improvements and environmental reporting) as the dependent variables (see Table II).

Insert Table II about here 
A competitiveness motivation was not related to either type of environmental proactivity, thus we did not find support for Hypothesis 1. In contrast, ecological responsibility had a significant positive relationship to both measures of environmental proactivity: Environmental operational improvements $(p<.01)$ and environmental reporting $(p<.10)$. Thus, Hypothesis 2 was supported

Stakeholder Pressure

To test Hypotheses 3 and 4 -which predicted that perceived external and regulatory stakeholder pressure would be positively related to environmental proactivity—we ran linear regressions across both our measures of environmental proactivity as the dependent variables (see Table II).

External stakeholder pressure was not significantly related to environmental operational improvements, and it had a significant negative relationship to environmental reporting $(p<.001)$. Thus, Hypothesis 3 was not supported.

Regulatory stakeholder pressure had a significant positive relationship to both measures of environmental proactivity: Environmental operational improvements $(p<$ $.10)$ and environmental reporting $(p<.001)$. Thus, Hypothesis 4 was supported.

The results for our antecedents to environmental proactivity are displayed in Figure 2 .

Insert Figure 2 about here

Competitive Advantage

To test Hypotheses 5 and 6 for the moderating effects of motivations we ran four regressions that tested the interactions of motivation and environmental proactivity by both types of competitive advantage: cost advantage and reputation (see Table III). In addition, we included innovation to test the null hypothesis of no 
significant relationship among motivation, environmental proactivity and innovation. Since we did not form a hypothesis we do not show the result in the Table, but as predicted it was not significant.

We found three significant interactions (see Table III). First, the interaction between one environmental proactivity measure (i.e., environmental operational improvements) and an ecological responsibility motivation was significant and positive for cost advantage $(p<.01)$. We further examined this significant interaction by plotting it in Figure 3 (Aiken and West, 1991). The plotted interaction shows that for managers of firms with an ecological motivation as their environmental operational improvements increased their perceived cost advantage increased. This is in contrast to managers that are not ecologically motivated who perceived a decreased cost advantage as their environmental operational improvements increased. This significant interaction indicates that while the relationship between environmental operational improvements and cost advantage is not significant, if the managers of a firm are environmentally proactive (measured through operational improvements) and they are ecologically motivated, there is a perceived positive and significant cost advantage.

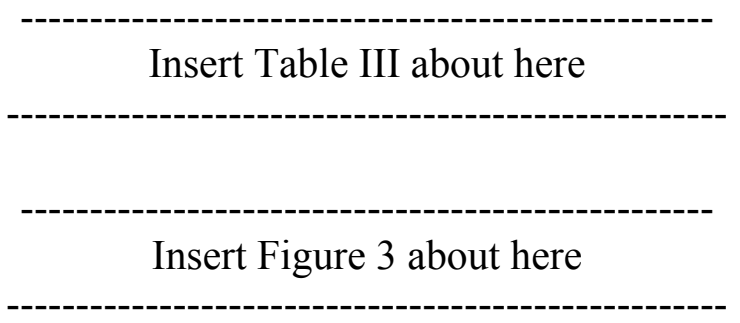

Second, the interaction between the other measure of environmental proactivity (i.e., environmental reporting) and an ecological responsibility motivation was also significant and positive for cost advantage $(p<.01)$. We further examined this significant interaction by plotting it in Figure 4 (Aiken and West, 1991). The 
plotted interaction shows that for managers in firms with an ecological motivation, as their environmental reporting increased their perceived cost advantage increased. This is in contract to managers of firms that are not ecologically motivated who perceived a decreased cost advantage as their environmental proactivity increased. Taking these two significant interactions together, we find support for hypothesis H5 that proposed that an ecological motivation would positively moderate the impact of environmental proactivity on cost advantage.

Insert Figure 4 about here

Third, consistent with Hypothesis H6, the interaction between environmental proactivity and a competitive motivation was significant and positive for reputation ( $p$ $<.05)$. However, it only occurred to environmental operational improvements and not to environmental reporting. We further examined the significant interaction by plotting it in Figure 5 (Aiken and West, 1991). The plotted interaction shows that for managers in firms with a competitive motivation, as their environmental operational improvements increased their perceived reputation advantage increased. This is in contrast to managers in firms that are not competitively motivated who perceived a decreased reputation advantage as their environmental proactivity increased. Thus we obtain partial support for Hypothesis 6 in that a competitive motivation did moderate the relationship between environmental operational improvements and a perceived reputation advantage, but this relationship did not exist for environmental reporting.

Insert Figure 5 about here

\section{Discussion}


Our results support the research contention that environmental proactivity is a multi-dimensional construct and that the one-size-fits-all approach to environmental management and research is limited and misleading (Barnett, 2007; Berchicci and King, 2007; Brammer and Millington, 2008). Such support is evident in two ways: First, our data indicates the existence of two types of environmental proactivity with similarities and differences in regards to their respective antecedents and consequences. Second, our results delineate notable differences between environmental proactivity in Western societies versus that in China. We examine the latter point throughout the discussion.

We found that both an ecologically responsible motivation and perceived regulatory stakeholder pressure had a significant positive relationship to both types of environmental proactivity. The first finding indicates that in contrast to motivations driven by competitiveness those driven by ecological responsibility further a firm's environmental proactivity. A large amount of research examining environmental proactivity in Western countries has tried to encourage greater firm proactivity by empirically identifying the financial benefits to doing so (Ambec and Lanoie, 2008; Hart, 1995; Miles and Covin, 2000; Orlitzky et al., 2003; Porter and van der Linde, 1995; Russo and Fouts, 1997). However, our research of Chinese firms demonstrates that a competitive motivation does not increase environmental proactivity. Only firms that are ecologically driven have a significant and positive relationship to environmental proactivity. Furthermore, the financial benefits measured through a cost advantage appear to be attainable only when the firm is ecologically motivated (as identified through our interaction effects). That is, there were no direct relationships between our two types of environmental proactivity and cost advantage, but when ecologically motivated, both types were related to significant cost 
advantages. Thus, Chinese managers seeking to gain cost advantages over their competitors through their environmental proactivity must be motivated by the belief that it is the right thing to do from a moral and ethical standpoint. It is possible that without this motivation managers seek short cuts or are not fully committed to environmental proactivity resulting in an inability to obtain any cost advantages.

Research has consistently found that government regulations can lead to environmental proactivity (e.g., Marcus and Geffen, 1998; Majumdar and Marcus, 2001). It would appear that this effect also applies to China as perceived regulatory stakeholder pressure had a significant and positive relationship to both types of environmental proactivity. Through coercive pressures governments can motivate environmental proactivity. This finding again demonstrates the ability of governments to enforce environmental proactivity, as consistent with previous studies on corporate environmental management of Chinese firms (Zhang et al., 2008; Zhu et al., 2007).

Contrary to what we hypothesized, perceived external stakeholder pressure was negatively related to environmental reporting and not related to environmental operational improvements. While researchers have found that external stakeholders from developed countries are pressuring Chinese firms in their supply chain to increase their environmental performance (Lai and Wong, 2012; Zhu et al., 2007), we did not find evidence of this in our data. It may be that the specific external stakeholders examined in our data (customers, suppliers, trade associations, competitors and banks) are price driven and Chinese managers feel pressure to keep costs as low as possible. For example, Chinese managers may not want to invest in employee environmental training or internal and external environmental accounting (items in our constructs) as such activities will increase short-term costs. Thus, even though environmental proactivity may result in cost savings over time through things 
such as waste reduction and closed-loop systems, given the short-term costs of implementation managers may not have been willing to invest the necessary amount of firm resources given external stakeholder pressures for minimal costs.

Arguably, our most interesting findings relate to the examination of the relationship between environmental proactivity and competitive advantage as tested in the interaction effect terms. First, as expected, we did not find any signification relationship between motivation, environmental proactivity and innovation. This demonstrates the limited value of environmental proactivity related to innovation for our sampled Chinese firms.

Second, to gain a reputation advantage through environmental proactivity senior managers must be competitively motivated. This finding is entirely consistent with the most commonly used definition of reputation (Walker, 2010) provided by Fombrun (1996: 72) that implies competition with rivals. Given this conceptualization of reputation it is not surprising that a reputational advantage to environmental proactivity occurs when managers are competitively motivated. In other words, in order to gain a reputation advantage, managers need to be motivated by competition so that they are always seeking to do more than their competitors and are thus perceived as the more environmental proactive firm to stakeholders.

Third, two significant interactions were identified between environmental proactivity and cost advantage, which demonstrated that in order to gain a cost competitive advantage through either type of environmental proactivity firms must be ecologically motivated. This relationship is of particular interest given that we did not find a significant direct relationship between environmental proactivity and cost competitive advantage. Without being motivated by ecological responsibility managers may not be willing to make the necessary short-term investments to 
ultimately gain a cost advantage over competitors. The paradox of these two findings is that to gain a cost advantage managers cannot be motivated by competition, only by ecological responsibility. Managers of firms that do gain a cost advantage to their environmental proactivity will no doubt be pleased, but interestingly this is not why they are engaged in environmental proactivity in the first place. It may be the case that when top managers state that their motivation for environmental proactivity is ethical or moral employees are more likely to embrace the proactivity as it filters down the organization. This embracement may then result in additional cost savings as various employees find the means through which to continue to improve the firm's environmental proactivity. Similarly, with the support of top management the organizational culture will be strongly supportive of environmental proactivity. Perhaps, only with a culture that embraces environmental proactivity as the ethical or moral thing to do, are firms able to gain a cost competitive advantage.

Implications

Research implications. For researchers our implications are threefold: First, with a dearth of research examining environmental proactivity in emerging markets our research in China demonstrates the existence of environmental proactivity (meaning a non-zero value for the measure) and some compelling differences and similarities with research results from emerged markets. Given that both emerged and emerging countries will need to be a part of the discussions and ultimate solutions to global environmental problems such as climate change, our research demonstrates that we have much to learn about environmental proactivity in emerging countries.

Second, our research supports the contention that environmental management is not a universal prescription or a one-size-fits-all approach (Barnett, 2007; Berchicci and King, 2007; Brammer and Millington, 2008). We found evidence of two types of 
environmental proactivity that had similarities and differences with regards to the antecedents and consequences of proactivity, and some notable differences between environmental proactivity in Western societies versus that in China. Differences included (1) a non-significant relationship between a competitive motivation and environmental proactivity, (2) a negative relationship between external stakeholders and environmental proactivity, (3) a non-significant relationship between environmental proactivity and innovation, (4) a non-significant relationship between environmental proactivity and a cost advantage but a significant relationship when ecologically motivated, and (5) a non-significant relationship between environmental proactivity and a reputation advantage but a significant relationship (to operational improvements specifically) when competitively motivated. Furthermore, the use of multiple forms of competitive advantage was substantiated in that we obtained very different results across cost, reputation and innovation.

Third, we uncovered a paradox where managers must be motivated by ecological responsibility to gain a perceived cost advantage. This is a compelling result as it differs from research examining Western organizations, and provides opportunities for future research to begin to examine this paradox in greater detail. For example, does this paradox exist in other parts of China? Can we empirically identify the reasons for its occurrence? Given that our results were self-reported, is the perceived cost advantage actual, or are managers that engage in environmental proactivity because they believe it is the right thing to do overly optimistic on the financial benefits?

Managerial implications. For managers our implications are threefold: First, both our measures of environmental proactivity are related to a cost competitive advantage, but to obtain it, top managers must paradoxically be motivated by 
ecological responsibility, not competition. Managers seeking to gain a cost advantage must create a culture that believes in environmental proactivity because it is the right thing to do (Bansal and Roth, 2000), and not because they seek to minimize costs. Second, while there was no direct relationship between environmental operational improvements and a reputation competitive advantage, managers can gain this advantage as long as they are motivated by competition. Therefore, managers cannot gain a cost advantage when their environmental proactivity is motivated by competition, but they can gain a reputation advantage. Third, we found no significant relationships related to innovation. Knowing this, if managers could conscientiously attempt to further innovation through environmental proactivity they could potentially be in unique possession of an innovation competitive advantage.

Policy implications. For policy makers our implications are threefold: First, if your goal is to increase the environmental proactivity in China you are succeeding in that the managers in our sample felt pressured by regulatory stakeholders to become proactive. Second, in making appeals to further corporate environmental proactivity, our data suggests that the best means to do so would be to make arguments that it is the ethical or moral thing to do (ecological responsibility). Arguments based on competition, such as arguing that it will improve the bottom-line, are not strongly supported in our data. Paradoxically, arguments based on ethical or moral appeals can be sold by stating that only with such motivation can competitive gains in cost be obtained. Third, the lack of any significant relationships to an innovation competitive advantage should be troubling to policy makers in China. Firm innovation is necessary for competitiveness and if Chinese firms are not innovating as it relates to environmental proactivity it may mean that they are seeking such innovation 
elsewhere. Policy makers may want to create policies to encourage home grown environmental innovation.

Limitations and Future Research

Our study had two main limitations. First, we discussed our results as though they were representative of all of China. However, our findings are specific to the city of Zigong located in the Sichuan province in southwest China, and they may not generalize beyond this location. That said, we purposely selected Zigong given that this area typifies most corporations (including small and medium sized enterprises) in such a transitional economy and their felt pressures or motivations related to proactive environmental management practices. Future research will have to investigate other parts of China to see if our results are generalizable.

Second, there was no archival and publicly available data for any of our measures within our study context, and it was therefore necessary to use crosssectional survey data. While such data has its advantages over archival publicly available data (Delmas et al., 2011) we were not able to conduct a longitudinal investigation or use more objective measures for our constructs. In the future, researchers may be in a position to examine environmental proactivity longitudinally and perhaps using secondary data within our study context.

\section{Conclusion}

We empirically identified a number of antecedents and consequences to environmental proactivity in China. In particular, we found that ecological motivations and regulatory stakeholder pressure were positively related to both types of environmental proactivity, and that external stakeholder pressure was negatively related to environmental reporting. Furthermore, we found that (1) if a firm was environmentally proactive (as it relates to either measure) and they were ecologically 
motivated, there was a positive and significant cost advantage, and (2) if a firm makes use of environmental operational improvement and they were competitively motivated, there was a positive and significant reputation advantage.

Despite being the world's second largest economy, the largest emitter of carbon dioxide, and a country that burns twice as much coal as the United States (Gore, 2009), we know surprisingly little about environmental proactivity in China. One of the most influential Chinese spiritual leaders Lao Tzu stated "A journey of a thousand miles must begin with a single step" (Dyer, 2008). We hope our study sheds light on this journey, as China's involvement in global environmental proactivity is a must if we are to overcome the major environmental problems we face today. 


\section{References}

Aldrich, H.E. and C.M. Fiol: 1994, 'Fools Rush in? the Institutional Context of Industry Creation', Academy of Management Review 19(4), 645-670.

Ambec, S. and P. Lanoie: 2008, 'Does it Pay to be Green? A Systematic Overview', Academy of Management Perspectives 22(4), 45-62.

Amit, R. and P.J.H. Schoemaker: 1993, 'Strategic Assets and Organizational Rent', Strategic Management Journal 14(1), 33-46.

Anderson, L.M. and T.S. Bateman: 2000, 'Individual Environmental Initiative: Championing Natural Environmental Issues in U.S. Business Organizations', Academy of Management Journal 43(4), 548-570.

Aragón-Correa, J.A. and S. Sharma: 2003, 'A Contingent Resource-Based View of Proactive Corporate Environmental Strategy', Academy of Management Review 28(1), 71-88.

Aragón-Correa, J.: 1998, 'Research Notes. Strategic Proactivity and Firm Approach to the Natural Environment', Academy of Management Journal 41(5), 556-567.

Arora, S. and T.N. Cason: 1996, 'Why do Firms Volunteer to Exceed Environmental Regulations? Understanding Participation in EPA's 33/50 Program ', Land Economics 72(4), 413-432.

Banerjee, S.B.: 2001, 'Managerial Perceptions of Corporate Environmentalism: Interpretations from Industry and Strategic Implications for Organizations', Journal of Management Studies 38(4), 489-513.

Banerjee, S.B., E.S. Iyer and R.K. Kashyap: 2003, 'Corporate Environmentalism: Antecedents and Influence of Industry Type', Journal of Marketing 67(2), 106-122.

Bansal, P. and J. Gao: 2006, 'Building the Future by Looking at the Past: Examining Published Research in Organizations and Environment', Organization \& Environment 19(4), 458-478.

Bansal, P. and W.C. Bogner: 2002, 'Deciding on ISO 14001: Economics, Institutions, and Context', Long Range Planning 35(3), 269-290.

Bansal, P. and K. Roth: 2000, 'Why Companies Go Green: A Model of Ecological Responsiveness', Academy of Management Journal 43(4), 717-736.

Berchicci, L. and A. King: 2007, 'Chapter 11: Postcards from the Edge', Academy of Management Annals 1(1), 513-547.

Berrone, P., C. Cruz, L. Gomez-Mejia and M. Larraza-Kintana: 2010, 'Socioemotional Wealth and Corporate Responses to Institutional Pressures: Do 
Family-Controlled Firms Pollute Less?', Administrative Science Quarterly 55(1), 82113.

Berrone, P. and L. Gomez-mejia: 2009, 'Environmental Performance and Executive Compensation: An Integrated Agency-Institutional Perspective', Academy of Management Journal 52(1), 103-126.

Boiral, O.: 2007, 'Corporate Greening through ISO 14001: A Rational Myth?', Organization Science 18(1), 127-146.

Bragdon, H. and J. Marlin: 1972, 'Is Pollution Profitable?', Risk Management 19(4), 918.

Brammer, S. and A. Millington: 2008, 'Does it Pay to be Different? An Analysis of the Relationship between Corporate Social and Financial Performance', Strategic Management Journal 29(12), 1325-1343.

Buysse, K. and A. Verbeke: 2003, 'Proactive Environmental Strategies: A Stakeholder Management Perspective', Strategic Management Journal 4(5), 453-470.

Cheah, E., D. Jamali, J.E.V. Johnson and Ming-Chien Sung: 2011, 'Drivers of Corporate Social Responsibility Attitudes: The Demography of Socially Responsible Investors', British Journal of Management 22(2), 305-323.

Child, J. and T. Tsai: 2005, 'The Dynamic between Firms' Environmental Strategies and Institutional Constraints in Emerging Economies: Evidence from China and Taiwan', Journal of Management Studies 42(1), 95-125.

Christmann, P.: 2000, 'Effects of "Best Practices" of Environmental Management on Cost Advantage: The Role of Complementary Assets', Academy of Management Journal 43(4), 663-680.

Christmann, P. and G. Taylor: 2001, 'Globalization and the Environment: Determinants of Firm Self-Regulation in China', Journal of International Business Studies 32(3), 439-458.

Clelland, I.J., T.J. Douglas and D.A. Henderson: 2006, 'Testing Resource-Based and Industry Factors in a Multi-Level Model of Competitive Advantage Creation', Academy of Strategic Management Journal 5, 1-24.

Dahlmann, F. and S. Brammer: 2011, 'Exploring and Explaining Patterns of Adaptation and Selection in Corporate Environmental Strategy in the USA', Organization Studies 32(4), 527-553.

Darnall, N., I. Henriques and P. Sadorsky: 2010, 'Adopting Proactive Environmental Strategy: The Influence of Stakeholders and Firm Size', Journal of Management Studies 47(6), 1072-1094.

Davis, G.F. and T.A. Thompson: 1994, 'A Social Movement Perspective on Corporate Control', Administrative Science Quarterly 39(1), 141-173. 
de Villiers, C., V. Naiker and C.J. van Staden: 2011, 'The Effect of Board Characteristics on Firm Environmental Performance', Journal of Management 37(6), 1636-1663.

Dean, T.J. and R.L. Brown: 1995, 'Pollution Regulation as a Barrier to New Firm Entry: Initial Evidence and Implications for Future Research', Academy of Management Journal 38(1), 288-303.

Delmas, M.A., V.H. Hoffmann and M. Kuss: 2011, 'Under the Tip of the Iceberg: Absorptive Capacity, Environmental Strategy, and Competitive Advantage', Business \& Society 50(1), 116-154.

Delmas, M.A. and M. Montes-Sancho: 2010, 'Voluntary Agreements to Improve Environmental Quality: Symbolic and Substantive Cooperation', Strategic Management Journal 31(6), 575-601.

Delmas, M.A. and I. Montiel: 2008, 'The Diffusion of Voluntary International Management Standards: Responsible Care, ISO 9000, and ISO 14001 in the Chemical Industry', Policy Studies Journal 36(1), 65-93.

Delmas, M.A. and M.W. Toffel: 2008, 'Organizational Responses to Environmental Demands: Opening the Black Box', Strategic Management Journal 29(10), $1027-$ 1055.

DiMaggio, P.J. and W.W. Powell: 1983, 'The Iron Cage Revisited: Institutional Isomorphism and Collective Rationality in Organizational Fields', American Sociological Review 48(2), 147-160.

Donaldson, T. and L.E. Preston: 1995, 'The Stakeholder Theory of the Corporation: Concepts, Evidence, and Implications', Academy of Management Review 20(1), 65-91.

Dyer, W.: 2008, Change Your Thoughts-Change Your Life: Living the Wisdom of the Tao, (Hay House).

Faucheux, S., I. Nicolai and M. O’Connor: 1998, 'Globalization, Competitiveness, Governance and Environment: What Prospects for a Sustainable Development?', in S. Faucheux and J. Gowdy (eds.), Sustainability and Firms, Technological Change and the Changing Regulatory Environment, (Massachusetts, Edward Elgar Publishing).

Fineman, S. and K. Clarke: 1996, 'Green Stakeholders: Industry Interpretations and Response', Journal of Management Studies 33(6), 715-730.

Fogler, H.R. and F. Nutt: 1975, 'A Note on Social Responsibility and Stock Valuation', Academy of Management Journal 18(1), 155-160.

Fombrun, C.: 1996, 'Reputation: Realizing Value from the Corporate Image' (Boston, MA, Harvard Business School Press).

Francesch-Huidobro, M., C.W. Lo and S. Tang: 2012, 'The Local Environmental Regulatory Regime in China: Changes in Pro-Environment Orientation, Institutional 
Capacity, and External Political Support in Guangzhou', Environment and Planning A 44(10), 2493-2511.

Freeman, R.: 1984, Strategic Management: A Stakeholder Approach, (Boston, MA, Pitman).

Gao, Y.: 2009, 'Corporate Social Performance in China: Evidence from Large Companies', Journal of Business Ethics 89(1), 23-25.

Gonzalez-Benito, J. and O. Gonzalez-Benito: 2006, 'A Review of Determinant Factors of Environmental Proactivity', Business Strategy \& the Environment 15(2), 87-102.

Gore, A.: 2009, our Choice: A Plan to Solve the Climate Crisis (Emmaus, PA, Rodale Inc).

Hart, S.L.: 2005, Capitalism at the Crossroads: The Unlimited Business Opportunities in Solving the World's most Difficult Problems, (Upper Saddle River, NJ, Wharton School Publishing).

Hart, S.L. and G. Ahuja: 1996, 'Does it Pay to be Green? An Empirical Examination of the Relationship between Emission Reduction and Firm Performance', Business Strategy \& the Environment 5(1), 30-37.

Hart, S.L.: 1995, 'A Natural-Resource-Based View of the Firm', Academy of Management. Academy of Management Review 20(4), 986.

Henriques, I. and P. Sadorsky: 1996, 'The Determinants of an Environmentally Responsive Firm: An Empirical Approach', Journal of Environmental Economics and Management 30(3), 381-395.

Hillman, A.J. and M.A. Hitt: 1999, 'Corporate Political Strategy Formulation: A Model of Approach, Participation, and Strategy Decisions', Academy of Management Review 24(4), 825-842.

Howard-Grenville, J.: 2007, 'Developing Issue-Selling Effectiveness Over Time: Issue Selling as Resourcing', Organization Science 18(4), 560-577.

Huang, P., X. Zhang and X. Deng: 2006, 'Survey and Analysis of Public Environmental Awareness and Performance in Ningbo, China: A Case Study on Household Electrical and Electronic Equipment', Journal of Cleaner Production 14(18), 1635-1643.

Hunt, C.B. and E.R. Auster: 1990, 'Proactive Environmental Management: Avoiding the Toxic Trap', Sloan Management Review 31(2), 7-18.

Ip, P.: 2008, 'Corporate Social Responsibility and Crony Capitalism in Taiwan', Journal of Business Ethics 79(1), 167-177. 
Jamali, D.: 2008, 'A Stakeholder Approach to Corporate Social Responsibility: A Fresh Perspective into Theory and Practice', Journal of Business Ethics 82(1), 213231.

Judge, W. and T. Douglas: 1998, 'Performance Implications of Incorporating Natural Environmental Issues into the Strategic Planning Process: An Empirical Assessment', Journal of Management Studies 35(2), 241-262.

Kassinis, G. and N. Vafeas: 2006, 'Stakeholder Pressures and Environmental Performance', Academy of Management Journal 49(1), 145-159.

Klassen, R.D. and D.C. Whybark: 1999, 'The Impact of Environmental Technologies on Manufacturing Performance', Academy of Management Journal 42(6), 599-615.

Kolk, A. and J. Pinkse: 2008, 'A Perspective on Multinational Enterprises and Climate Change: Learning from "an Inconvenient Truth"?', Journal of International Business Studies 39(8), 1359-1378.

Lai, K. and C.W.Y. Wong: 2012, 'Green Logistics Management and Performance: Some Empirical Evidence from Chinese Manufacturing Exporters', Omega 40(3), 267-282.

Lau, J. and P. Waldmeir: 2010, 'Fears Grow Over China Labour Unrest', Financial Times June(11), 16.

Lee, M.: 2011, 'Configuration of External Influences: The Combined Effects of Institutions and Stakeholders on Corporate Social Responsibility Strategies', Journal of Business Ethics 102(2), 281-298.

Lee, S.Y. and Seung-Kyu Rhee: 2007, 'The Change in Corporate Environmental Strategies: A Longitudinal Empirical Study', Management Decision 45(2), 196-216.

Li, W. and R. Zhang: 2010, 'Corporate Social Responsibility, Ownership Structure, and Political Interference: Evidence from China', Journal of Business Ethics 96(4), 631-645.

Liu, W. and D. Lu: 2002, 'Rethinking the Development of Economic Geography in Mainland China', Environment and Planning A 34(12), 2107-2126.

Liu, X., B. Liu, T. Shishime, Q. Yu, J. Bi and T. Fujitsuka: 2010, 'An Empirical Study on the Driving Mechanism of Proactive Corporate Environmental Management in China', Journal of Environmental Management 91(8), 1707-1717.

Li-Wen Lin: 2010, 'Corporate Social Responsibility in China: Window Dressing Or Structural Change?', Berkeley Journal of International Law 28(1), 64-100.

Lo, C.W., G.E. Fryxell and B. Van Rooij: 2009, 'Changes in Enforcement Styles among Environmental Enforcement Officials in China', Environment and Planning A 41(11), 2706-2723. 
Lo, C.W. and G.E. Fryxell: 2005, 'Governmental and Societal Support for Environmental Enforcement in China: An Empirical Study in Guangzhou', The Journal of Development Studies 41(4), 558-588.

Ma, X. and L. Ortolano: Environmental Regulation in China: Institutions, Enforcement, and Compliance, (NY, Rowan and Littlefield Publishers).

Madsen, P.M.: 2009, 'Does Corporate Investment Drive a "Race to the Bottom" in Environmental Protection? A Reexamination of the Effect of Environmental Regulation on Investment', Academy of Management Journal 52(6), 1297-1318.

Marcus, A. and D. Geffen: 1998, 'The Dialectics of Competency Acquisition: Pollution Prevention in Electric Generation', Strategic Management Journal 19(12), 1145-1168.

Mayer, D.M., M. Kuenzi, R. Greenbaum, M. Bardes and R. Salvador: 2009, 'How Low does Ethical Leadership Flow? Test of a Trickle-Down Model', Organizational Behavior and Human Decision Processes 108(1), 1-13.

Meyer, J. and B. Rowan: 1977, 'Institutional Organizations: Formal Structure as Myth and Ceremony', American Journal of Sociology 83, 340-363.

Miles, M.P. and J.G. Covin: 2000, 'Environmental Marketing: A Source of Reputational, Competitive, and Financial Advantage', Journal of Business Ethics 23(3), 299-311.

Milstein, M., S. Hart and A. York: 2002, 'Coercion Breeds Variation: The Differential Impact of Isomorphic Pressures on Environmental Strategies', in A. Hoffman and M. Ventresca (eds.), Organizations, Policy, and the Natural Environment. (Stanford, California, Stanford University Press), pp. 151-172.

Mitchell, R.K., B.R. Agle and D.J. Wood: 1997, 'Toward a Theory of Stakeholder Identification and Salience: Defining the Principle of Who and what really Counts', Academy of Management. Academy of Management Review 22(4), 853-886.

Murillo-Luna, J., C. Garcés-Ayerbe and P. Rivera-Torres: 2008, 'Why do Patterns of Environmental Response Differ? A Stakeholders' Pressure Approach', Strategic Management Journal 29(11), 1225-1240.

Pacala, S.: 2004, 'Stabilization Wedges: Solving the Climate Problem for the Next 50 Years with Current Technologies', Science 305(5686), 968-972.

Pfeffer, J. and G. Salancik: 1978, the External Control of Organizations: A Resource Dependence Perspective, (New York, Harper and Row).

Porter, M.E. and C. van der Linde : 1995, 'Toward a New Conception of the Environment-Competitiveness Relationship', Journal of Economic Perspectives 9(4), 97-118. 
Roome, N. and F. Wijen: 2006, 'Stakeholder Power and Organizational Learning in Corporate Environmental Management', Organization Studies 27(2), 235-263.

Rooney, C.: 1993, 'Economics of Pollution Prevention: How Waste Reduction Pays', Pollution Prevention Review 3(summer), 261-276.

Rueda-Manzanares, A., J.A. Aragón-Correa and S. Sharma: 2008, 'The Influence of Stakeholders on the Environmental Strategy of Service Firms: The Moderating Effects of Complexity, Uncertainty and Munificence', British Journal of Management 19(2), 185-203.

Schaefer, A.: 2007, 'Contrasting Institutional and Performance Accounts of Environmental Management Systems: Three Case Studies in the UK Water \& Sewerage Industry', Journal of Management Studies 44(4), 506-535.

Sharfman, M.P. and C.S. Fernando: 2008, 'Environmental Risk Management and the Cost of Capital', Strategic Management Journal 29(6), 569-592.

Sharfman, M.P., T.M. Shaft and L. Tihanyi: 2004, 'A Model of the Global and Institutional Antecedents of High-Level Corporate Environmental Performance', Business \& Society 43(1), 6-36.

Sharma, P. and S. Sharma: 2011, 'Drivers of Proactive Environmental Strategy in Family Firms', Business Ethics Quarterly 21(2), 309-334.

Sharma, S.: 2000, 'Managerial Interpretations and Organizational Context as Predictors of Corporate Choice of Environmental Strategy', Academy of Management Journal 43(4), 681-697.

Sharma, S. and I. Henriques: 2005, 'Stakeholder Influences on Sustainability Practices in the Canadian Forest Products Industry', Strategic Management Journal 26(2), 159180.

Sharma, S. and H. Vredenburg: 1998, 'Proactive Corporate Environmental Strategy and the Development of Competitively Valuable Organizational Capabilities', Strategic Management Journal 19(8), 729-753.

Siegel, P.H. and S. Agrawal: 1997, 'Organizational and Professional Socialization: Institutional Isomorphism in an Accounting Context', Mid-Atlantic Journal of Business 33(1), 49-68.

Somers, M.J.: 2001, 'Ethical Codes of Conduct and Organizational Context: A Study of the Relationship between Codes of Conduct, Employee Behavior and Organizational Values', Journal of Business Ethics 30(2), 186-195.

Su, Y.L. and Seung-Kyu Rhee: 2007, 'The Change in Corporate Environmental Strategies: A Longitudinal Empirical Study', Management Decision 45(2), 196-216.

Tang, S., C.W. Lo and G.E. Fryxell: 2003, 'Enforcement Styles, Organizational Commitment, and Enforcement Effectiveness: An Empirical Study of Local 
Environmental Protection Officials in Urban China', Environment and Planning A 35(1), 75-94.

Tang, S. and X. Zhan: 2008, 'Civic Environmental NGOs, Civil Society, and Democratisation in China', Journal of Development Studies 44(3), 425-448.

Tao, J. and D.N. Mah: 2009, 'Between Market and State: Dilemmas of Environmental Governance in China's Sulphur Dioxide Emission Trading System', Environment and Planning C: Government and Policy 27(1), 175-188.

Turban, D.B. and D.W. Greening: 1997, 'Corporate Social Performance and Organizational Attractiveness to Prospective Employees', Academy of Management Journal 40(3), 658-672.

Van Rooij, B.: 2006, Regulating Land and Pollution in China: Lawmaking, Compliance, and Enforcement; Theory and Cases, (Leiden, Leiden Univ. Press).

Walker, K.: 2010, 'A Systematic Review of the Corporate Reputation Literature: Definition, Measurement, and Theory', Corporate Reputation Review 12(4), 357-387.

Walker, K. and Wan, F. 2012. 'The Harm of Symbolic Actions and Green-Washing: Corporate Actions and Communications on Environmental Performance and Their Financial Implications Journal of Business Ethics 109(2), 227-242.

Wang, H. and C. Qian: 2011, 'Corporate Philanthropy and Corporate Financial Performance: The Roles of Stakeholder Response and Political Access', Academy of Management Journal 54(6), 1159-1181.

Whiteman, G. and W.H. Cooper: 2011, 'Ecological Sensemaking', Academy of Management Journal 54(5), 889-911.

Yang, G.B.: 2005, 'Environmental NGOs and Institutional Dynamics in China', The China Quarterly 181, 46-66.

Ye, K. and R. Zhang: 2011, 'Do Lenders Value Corporate Social Responsibility? Evidence from China', Journal of Business Ethics 104(2), 197-206.

Yuan, Z., J. Bi and Y. Moriguichi: 2006, 'The Circular Economy: A New Development Strategy in China', Journal of Industrial Ecology 10(1-2), 4-8.

Zhang, B., J. Bi, Z. Yuan, J. Ge, B. Liu and M. Bu: 2008, 'Why do Firms Engage in Environmental Management? an Empirical Study in China', Journal of Cleaner Production 16(10), 1036-1045.

Zhu, Q., J. Sarkis and K. Lai: 2007, 'Green Supply Chain Management: Pressures, Practices and Performance within the Chinese Automobile Industry', Journal of Cleaner Production 15(11), 1041-1052. 